\title{
GEOGRAPHY WEBSITE ANALYSIS. THE CASE OF http://www.profudegeogra.eu/ IN ROMANIA
}

\author{
MANUELA GAVRIȘ \\ "Babeş-Bolyai" University, Faculty of Geography, Cluj-Napoca, Romania, \\ e-mail: gavris_manuela1993@yahoo.com
}

(Received: January 2015; in revised form: February 2015)

\begin{abstract}
The research started in response to the findings that http://www.profudegeogra.eu/ is one of the best known websites among the Romanian websites concerning geographical issues. This article examines the resources offered by this website, their relevance and how they help students and even teachers in the activity of learning or teaching Geography. To quantify the popularity and the utility of this website, we applied a questionnaire to a target group represented by 27 students of various university majors of the Faculty of Geography, "Babeș-Bolyai" University, ClujNapoca, Romania.
\end{abstract}

Keywords: e-Learning, online, internet, tests, maps, web sources

\section{INTRODUCTION}

Information and communication technology has exponentially grown in the recent years, leading to a true revolution in the field of e-Learning.

More and more pupils, students and teachers put books, dictionaries and printed encyclopaedias aside in favour of electronic information offered by a multitude of web sources, readily and easily accessible to anyone. In the online world, there are many Romanian geographical themed websites and blogs, of which we could mention:

- geografialumii.ro; 
- geografilia.blogspot.com;

- profudegeogra.eu;

- didactic.ro.

A simple search on Google.ro using the following entries: "Geography Baccalaureate preparation" delivered 146,000 results in 0.44 seconds (January $15^{\text {th }}, 2015$ ). Following this search, the website http://www. profudegeogra.eu/ was ranked unexpectedly high in the top of the results list, being on the second place. Therefore, there is a high probability for twelfth graders to access this website while preparing for the Geography exam of the Baccalaureate, which prompted us to analyze it in this research.

Just as great is the likelihood for students or Geography teachers to access this website after a simple search on Google.ro, looking for different geographical terms, as well as information about specific countries or relief units, as this website brings together a wide variety of geographic information. After searching for the following phrases, the website was ranked again very high at the top of the list of results: "blind map" (first place), "geographic superlatives" (third place after Wikipedia and travel.descopera.ro), "Geography game" (second place after online.seterra.net), "Romanian cities" (on the sixth place), "relief on loess" (on the second place after the Wikipedia website).

The website http://www. profudegeogra.eu/ addresses children, pupils, Geography students, or adults who need various maps (tourist maps, subway or public transportation maps, road maps etc). In this research we analyze the resources offered by this website, their relevance and how they help students and even teachers in their activities of learning or teaching Geography.

\section{METHODS}

In the first stage of this research, we analyzed the structure of the website in order to identify the categories of resources offered in each section. This analysis focused particularly on the structure of the website.

In the second stage, we analyzed each category of resources (BAC 2012, Maps, Teaching Resources, Miscellaneous, Games, Fun, and Archive) and the resources posted in each category.

In the third stage we analyzed some of the comments posted by users on this website and applied a questionnaire to students from various university majors (Geography, Geography of Tourism, Hydrology, Meteorology, and Cartography) from the Faculty of Geography, "BabeșBolyai" University in Cluj-Napoca, Romania. The survey was sent to students via e-mail, indicating that their responses are analyzed keeping the anonymity of the respondents. 
The survey consisted of 7 items: two items of binary discrimination ( 1 and 2), three multiple choice items (3-5) and two items (6 and 7) in which students were required to score a couple of resources provided by the website on a scale of 1 to 5 , according to their utility and relevance. A total of 27 students responded to this survey.

\section{RESULTS AND DISCUSSONS}

The website www.profudegeogra.eu was created in May 2011, when the first articles were posted. This website totals 1,057 posts on various topics, written or uploaded within four years (2011-2014). The website also has a Facebook page called "Profu' de geogra" [the Geography teacher], created in 2011 as well.

The name of the website ("Profu' de geogra") was an inspired choice because it uses a colloquial language, which attracts young people. In Romanian, the word "profu" is the short version of the word "professor" or "teacher", used mainly by pupils or students when they talk to each other. This name contrasts with the image of the teacher in the classroom, as students and pupils perceive: tough, strict and serious, and so the author assigns himself a friendly, compassionate and selfless personality. It is expected that young people, pupils and students would access a website called "Profu' de geogra" with more confidence than one called "Didactic.ro".

When accessing this website, a pop-up window appears: "It takes many hours of work to keep this site! Support Profu' de geogra with a LIKE! Thnx!". This text continues to appear when accessing the site even after the user has hit the "LIKE" button on its Facebook page, and it can get tedious after a while.

However, the website promotes many commercials, especially some dynamic ones, which distract and bother the user. Thus, each page corresponding to a post starts with an advertisement which consists of five alternating pictures, changing at an interval of one second.

\section{Analysis of the categories of resources provided by the website}

The resources offered by the website are grouped within 10 sections: About, Bac 2012, Maps, Teaching resources, Miscellaneous, Games, Download books, Fun, Let's talk about it, Archive. Out of these, the sections of Bac 2012, Maps, Teaching resources, Miscellaneous and Games have subcategories, while the others are distinctive pages with various resources and posts (books, jokes, interesting information, archive etc.).

The first section, entitled About, sends us to a page where the author described in a few words the purpose he wanted to achieve when he designed this website. "This blog helps Geography students, teachers, and geographical science enthusiasts in order to fully understand the nature processes and phenomena. I will try to post as many specialized books on this site (found on the internet, scanned by me or purchased on the 
internet), geographical themed articles, maps or tests, geographical themed games or other geographical links" (the Author).

The owner of this website has not revealed their identity. We can only assume that the author of the website is a Geography teacher. By hiding his identity, the author only succeeds to decrease the reliability of the information provided. Some materials (.pdf books) are published without the authors consent (case of the book written by author Maria Eliza Dulamă, and of the "Topography. Cartography" book, $2^{\text {nd }}$ edition, 2005, by the authors Anton Năstase, Gabriela Osaci-Costache, Publishing House of the Foundation "România de Mâine", Bucharest (http://www. profudegeogra.eu/topografie-si-cartografie/).

The second section, BAC 2012 links to some useful resources for high school students and teachers for their personal training or preparing lessons and tests for students in the class.

The materials posted in the Maps category address different audiences. This section links to a wide variety of physical maps, administrative maps, travel maps etc., or plans of transportation networks of various European cities.

The materials posted in the Teaching Resources category are primarily intended for teachers, providing assessment tests, worksheets and other materials they could use in the classroom.

The fifth section, entitled Miscellaneous, is divided into various subcategories: geographical superlatives, images with geographical content, explanatory videos and documentaries, etc.

The Games section is suitable for pupils of various ages. Many games are posted, which can help pupils easily learn about certain administrative, hydrographical or relief units.

The section Fun links to 10 articles with jokes and funny pictures.

The section Let's talk about it can be found on the right side of the main menu and contains 217 articles on various interesting topics, with impressive pictures and texts, similar to the Terra magazine.

The section Archive sends the user to a page with all the headlines posted on the website from 2011 to the present. This page is useful for those who seek certain geographical information (e.g. the Carpathian Mountains) and want to find them in short time. 
Table 1. The structure of the website

\begin{tabular}{|c|c|c|c|c|c|c|c|c|}
\hline $\begin{array}{l}B a c \\
2012\end{array}$ & Maps & $\begin{array}{l}\text { Teaching } \\
\text { resources }\end{array}$ & Miscellaneous & Games & $\begin{array}{c}\text { Download } \\
\text { books }\end{array}$ & Fun & $\begin{array}{c}\text { Let's talk } \\
\text { about it }\end{array}$ & Archive \\
\hline $\begin{array}{l}100 \text { tests } \\
\text { with } \\
\text { answers }\end{array}$ & Europe & $\begin{array}{c}\text { Evaluation } \\
\text { sheets }\end{array}$ & Superlatives & $\begin{array}{l}\text { Identify on } \\
\text { games }\end{array}$ & & & & \\
\hline $\begin{array}{c}\text { Complete } \\
\text { Baccalaureat } \\
\text { e training } \\
\text { material }\end{array}$ & Romania & $\begin{array}{l}\text { Assessment } \\
\text { tests }\end{array}$ & $\begin{array}{l}\text { Geography in } \\
\text { pictures }\end{array}$ & $\begin{array}{c}\text { Game- } \\
\text { What shall } \\
\text { Santa Claus } \\
\text { bring you? }\end{array}$ & & & & \\
\hline \multirow[t]{4}{*}{$\begin{array}{c}\text { Game } \\
\text { training for } \\
\text { Baccalaureate }\end{array}$} & $\begin{array}{c}\text { Physical and } \\
\text { demographic } \\
\text { maps }\end{array}$ & $\begin{array}{l}\text { Teaching } \\
\text { materials }\end{array}$ & $\begin{array}{l}\text { Calendars, } \\
\text { schedules, cards }\end{array}$ & $\begin{array}{l}\text { BAC training } \\
\text { - Europe } \\
\text { and } \\
\text { Romania }\end{array}$ & & & & \\
\hline & $\begin{array}{c}\text { Interactive } \\
\text { maps }\end{array}$ & & $\begin{array}{l}\text { Romanian } \\
\text { Mountains from } \\
\mathrm{A} \text { to } \mathrm{Z}\end{array}$ & $\begin{array}{l}\text { Animal } \\
\text { MEMO }\end{array}$ & & & & \\
\hline & $\begin{array}{c}\text { Mountain } \\
\text { maps }\end{array}$ & & Did you know? & $\begin{array}{l}\text { GEO Snake } \\
\text { Game }\end{array}$ & & & & \\
\hline & Blind maps & & Video & $\begin{array}{c}\text { Geography } \\
\text { Test }\end{array}$ & & & & \\
\hline
\end{tabular}

\section{Analysis of the resources offered by the website for Baccalaureate}

The section Bac 2012 is divided into three subcategories: 100 tests with answers, Complete Baccalaureate Training Material, Game Training for the Baccalaureate (Table 1). The 100 tests with answers are designed according to the Baccalaureate program, and students can download them after subscribing with their e-mail address, and the tests will be sent to them by e-mail. In the Comments section, some students seemed pleased to have received the free tests in short time and declared that they have been very helpful for them, while others complained about not receiving those materials on time.

Another resource dedicated to preparing for the baccalaureate is entitled Complete Baccalaureate Training Material. It comprises of a set of video lessons, tests and a Baccalaureate preparation guide that students can receive after paying the amount of 14.99 lei. The author/authors of these materials are not mentioned, and neither are the sources which they were taken from. The Baccalaureate preparation guide contains a summary of all the lessons, structured according to the curriculum, and 20 video lessons about the relief of Europe ( 7 videos) and the relief of Romania ( 13 videos).

The third available resource, offered to high school students, is a game that can be used while preparing for the Baccalaureate. We believe that this game is useful for students, but its effectiveness is not high since responses cannot be checked automatically and students cannot be warned when they picked the wrong answer.

We believe that the name of the section BAC 2012 is inappropriate and can cause confusion. Therefore, we suggest replacing it with one of the following names: "Training for $B A C$ ", "BAC" or "Learning for BAC". 


\section{Analysis of the maps provided on the website}

The section Maps is divided into the following categories: Europe, Romania, Physical and Demographic, Interactive, Mountain and Blind. They present, in turn, various subcategories (Table 2).

Some authors argue that online maps are indispensable in a studentcentred education (Osaci-Costache et al., 2014, p. 219) and they can „play many more roles in communicating an increasing number of types of information" (Buckley, \& Frye, 2011, p. 1).

For the European continent there are a lot of maps provided. They are not grouped by category, type or the surface they represent, or by another criterion. Physical and Demographic maps cover several areas or regions, countries or continents. This makes the documentation for a certain subject difficult, users being entirely entitled to rather prefer the Google search engine to find maps of certain regions or countries.

The maps are generally interesting and useful, but the website user may experience some problems. On many maps, the names of the cities or other elements are not written in Romanian, but in the national language of the respective country (for example, the maps of Ukraine, Greece, Germany, etc. ).

Also, some of these maps have a very low resolution, not legible even after enlargement (e.g. the map of Spain or of Sweden). Some maps have wrong or incomplete names, they either do not specify the type of the map, or the area represented does not match title given to the map.

For example, the Map of England should be called, in fact, "Map of the United Kingdom of Great Britain and Northern Ireland". Some maps in the subcategory Maps for BAC - Europe were processed for teaching purposes, but without respecting the cartography rules (e.g. maps of the physical-geographical units in Europe). Osaci-Costache (2012, p. 126) states that "it is exactly their wide dissemination and the ease with which they can be taken from the virtual environment what makes maps that contain errors to be potentially dangerous."

Another problem is that in the case of most of these maps, the author, the year of creation or the source from which they were taken cannot be identified. We also emphasize that the accuracy of the maps should be checked before publishing them.

The Interactive maps section has a name that attracts readers' interest. There are three maps posted: The map of vegetation in Romania, The map of slopes and ski resorts in Romania and The map of protected areas in Romania.

In the category of Mountain maps, tourist maps of the mountains in Romania are provided. They are useful to those interested in certain trails, markings and attractions in the mountainous areas of the country.

The category of Blind maps contains maps of several regions in Romania, in Europe or countries of other continents. They are especially useful to teachers in assessing students' knowledge, and also for students' self-evaluation. The method of blind maps is used in Romania at the Baccalaureate Exam and National Assessments for eighth grade pupils. 
Table 2. Maps provided on the website www. profudegeogra.eu

\begin{tabular}{|c|c|c|c|c|c|}
\hline Europe & Romania & $\begin{array}{l}\text { Physical and } \\
\text { demographic }\end{array}$ & Interactive & $\begin{array}{l}\text { Mountain } \\
\text { maps }\end{array}$ & Blind maps \\
\hline $\begin{array}{c}\text { Physical- } \\
\text { geographical } \\
\text { units in } \\
\text { Europe }\end{array}$ & $\begin{array}{c}\text { Administrative } \\
\text { or physical } \\
\text { maps of } \\
\text { counties }\end{array}$ & $\begin{array}{l}\text { Physical- } \\
\text { geographical units } \\
\text { in Europe }\end{array}$ & $\begin{array}{l}\text { Vegetation of } \\
\text { Romania }\end{array}$ & \multirow{17}{*}{$\begin{array}{c}\text { Different } \\
\text { maps of } \\
\text { the } \\
\text { mountains } \\
\text { in Romania }\end{array}$} & Romania \\
\hline $\begin{array}{c}\text { Physical- } \\
\text { geographical } \\
\text { units in } \\
\text { Central } \\
\text { Europe }\end{array}$ & Maps - cities & $\begin{array}{l}\text { Physical- } \\
\text { geographical units } \\
\text { in Central Europe }\end{array}$ & $\begin{array}{c}\text { Slopes and ski } \\
\text { resorts }\end{array}$ & & $\begin{array}{l}\text { Different } \\
\text { countries of the } \\
\text { world }\end{array}$ \\
\hline $\begin{array}{l}\text { Physical and } \\
\text { political } \\
\text { maps of } \\
\text { different } \\
\text { European } \\
\text { countries }\end{array}$ & $\begin{array}{c}\text { Maps - } \\
\text { transportation } \\
\text { networks }\end{array}$ & $\begin{array}{c}\text { Map of } \\
\text { earthquakes } \\
\text { around the world } \\
\text { between 1900- } \\
2007\end{array}$ & \multirow[t]{15}{*}{$\begin{array}{l}\text { Interactive } \\
\text { map of } \\
\text { protected } \\
\text { areas in } \\
\text { Romania }\end{array}$} & & $\begin{array}{l}\text { European } \\
\text { countries }\end{array}$ \\
\hline $\begin{array}{l}\text { Blind Map - } \\
\text { Rivers of } \\
\text { Europe }\end{array}$ & \multirow[t]{14}{*}{$\begin{array}{l}\text { Maps - relief } \\
\text { units }\end{array}$} & $\begin{array}{l}\text { Climate maps of } \\
\text { different countries }\end{array}$ & & & European rivers \\
\hline $\begin{array}{l}\text { Mineral } \\
\text { Resources } \\
\text { map }\end{array}$ & & $\begin{array}{l}\text { Physical maps of } \\
\text { different countries }\end{array}$ & & & Africa's regions \\
\hline $\begin{array}{l}\text { Geothermal } \\
\text { map }\end{array}$ & & $\begin{array}{c}\text { Tourist maps of } \\
\text { different countries }\end{array}$ & & & $\begin{array}{c}\text { The Meridional } \\
\text { (Southern) } \\
\text { Carpathians }\end{array}$ \\
\hline $\begin{array}{l}\text { Groundwate } \\
r \text { resources } \\
\text { map }\end{array}$ & & $\begin{array}{l}\text { Various maps of } \\
\text { Mexico, USA, } \\
\text { Canada, China, } \\
\text { Australia, Brazil, } \\
\text { India etc. }\end{array}$ & & & $\begin{array}{l}\text { The Oriental } \\
\text { Carpathians }\end{array}$ \\
\hline $\begin{array}{l}\text { Linguistic } \\
\text { map of } \\
\text { Europe }\end{array}$ & & $\begin{array}{c}\text { Ocean currents } \\
\text { map }\end{array}$ & & & $\begin{array}{c}\text { The Occidental } \\
\text { Carpathians }\end{array}$ \\
\hline $\begin{array}{l}\text { Map of } \\
\text { Religions in } \\
\text { Europe }\end{array}$ & & & & & $\begin{array}{c}\text { Lakes / rivers in } \\
\text { Europe }\end{array}$ \\
\hline $\begin{array}{c}\text { Forest } \\
\text { distribution } \\
\text { map }\end{array}$ & & & & & $\begin{array}{l}\text { Cities of } \\
\text { Romania }\end{array}$ \\
\hline $\begin{array}{l}\text { Vegetation } \\
\text { map }\end{array}$ & & & & & $\begin{array}{l}\text { Rivers of } \\
\text { Romania }\end{array}$ \\
\hline Rivers map & & & & & $\begin{array}{l}\text { Rivers on } \\
\text { different } \\
\text { continents }\end{array}$ \\
\hline Soils map & & & & & Map of the \\
\hline $\begin{array}{l}\text { Geological } \\
\text { map }\end{array}$ & & & & & Seas \\
\hline $\begin{array}{l}\text { Tectonic } \\
\text { map of } \\
\text { Europe }\end{array}$ & & & & & \\
\hline $\begin{array}{l}\text { Political map } \\
\text { of Europe }\end{array}$ & & & & & \\
\hline $\begin{array}{l}\text { Physical } \\
\text { map of } \\
\text { several }\end{array}$ & & & & & \\
\hline
\end{tabular}




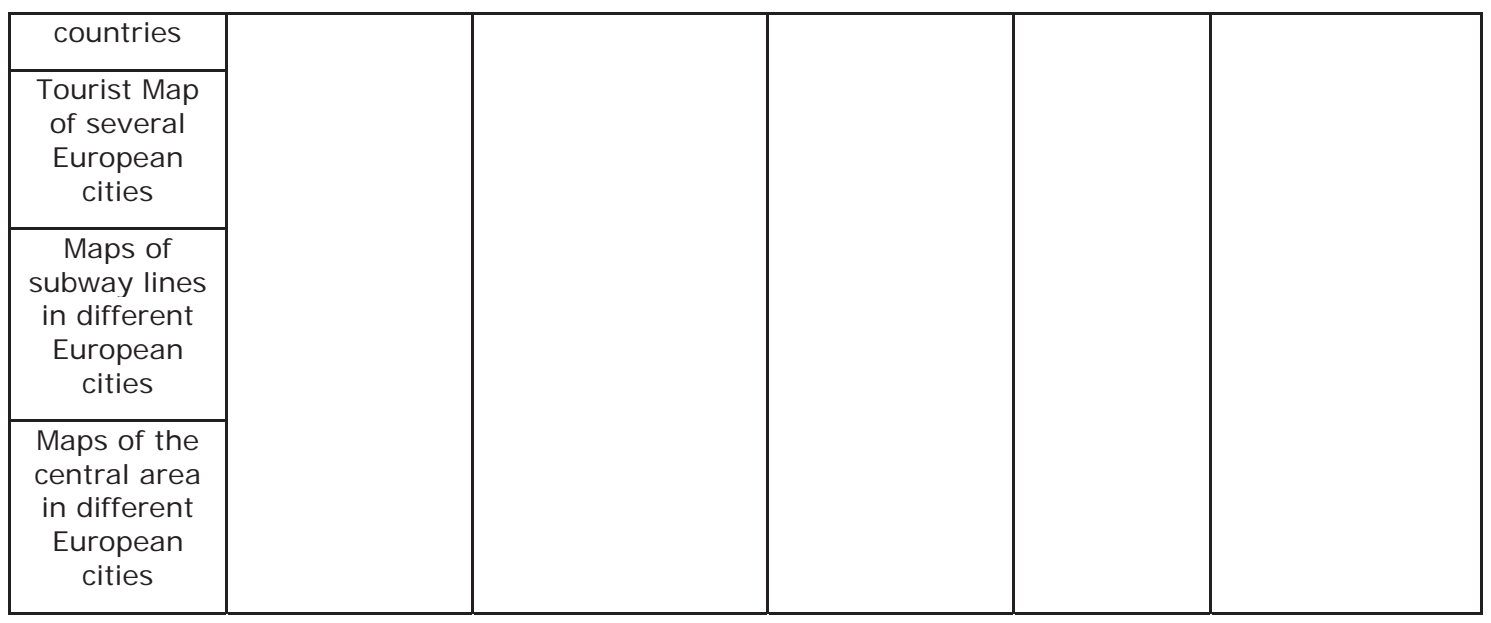

\section{Analysis of the teaching resources provided by the website}

The Teaching Resources section presents the following subcategories: Evaluation sheets, Assessment tests and Teaching materials. They are classified depending on the level of education to which they correspond, from the fifth grade to the twelfth grade.

We note the fact that the Evaluation sheets contain many tasks and they are not clearly formulated, while some of them have a low degree of difficulty. However, the fact that among worksheets the exercises based on silent maps prevail is a plus in any Geography evaluation, because getting to be acquainted with the Earth's surface through maps is one of the most important objectives of this discipline.

The Assessment tests include many items that demand the recognition of information and its evocation from memory (characterization of relief units, comparisons between two relief units or types of climate, etc.). Multiple choice items prevail, together with completing items, choice items true/false and pair items. A disadvantage for students who access evaluation tests is that they are not provided the correct answers, so students cannot check if their answer is right or wrong. Therefore, the assessment tests should and can be mainly used by teachers in the classroom.

In the subcategory of Teaching materials, users can find evaluation sheets with silent maps and different identification requirements, sketches of some landforms, various texts that come in hand for teachers (forms for school trips, schedule of national exams or contests, lesson planning sheets and lesson projects for various specializations, etc.). In most cases, the author and the source of the materials are not mentioned.

\section{Analysis of the resources provided in the Miscellaneous category}

In the category of Miscellaneous, various materials can be found, grouped into subcategories without any logical connection between them, but they are all interesting: Superlatives, Geography in pictures, Calendars, Schedules, Cards, the Romanian Mountains from A to Z, Did You Know?, and Video. Superlatives are also grouped in the following subcategories: Animals, Phenomena, Nature, and Territories. We consider this classification 
as erroneous, given that the third category - Nature, includes in reality the first two (Animals and Phenomena).

The subcategory Geography in pictures is divided into: Romania in images, Spectacle of nature and Geographical terms in images. These resources are useful for those passionate about curiosities, willing to learn more about the world they live in. They can be used even by teachers in class to stimulate students' curiosity and make lessons more interesting. In this context, we note that the both Romania in pictures and Spectacle of nature subcategory link to the same page, and the pages entitled Geographical terms in pictures and Spectacle of nature 1 are not active.

The subcategory Calendars, Schedules, Cards consist of the following posts: Environmental events calendar, Calendar 2012, Christmas cards, School calendar 2011-2012 and School timetable. Although these resources are interesting, they are not relevant to the particularity and specifics of this website.

In the subcategory Romanian Mountains from $A$ to $Z$ three posts are offered: Tourist attractions in the Ceahlău Mountains, Tourist attractions in Piatra Craiului and Tourist attractions in Bucegi. These include photographs of various attractions (e.g. Babele and Sphinx in Bucegi, Detunatele and Toaca peak in Ceahlău Mountain, etc.).

The subcategory Did you know? presents eight posts on different topics: rivers, lakes, animals, etc.

In the case of the Video subcategory, users can find several videos and pictures on various topics, made by the author of the website, but also some English videos from www. youtube.com recommended by the author.

Table 3. Resources provided in the category of Miscellaneous

\begin{tabular}{|c|c|}
\hline Superlatives & Animals \\
\hline & Phenomena \\
\hline & Nature \\
\hline & Territories \\
\hline Geography in & Romania in images \\
\hline pictures & Spectacle of nature \\
\hline & Geographical terms in images \\
\hline Calendars, & Calendars \\
\hline Schedules, & Schedules \\
\hline Cards & Cards \\
\hline Romanian Mour & tains from $A$ to $Z$ \\
\hline Did you know? & \\
\hline Video & \\
\hline
\end{tabular}

\section{Analysis of the games on the website}

The games on the website are probably the most used resource by the schoolchildren and high school students that are preparing for tests, National Exams or Baccalaureate. They are divided into the following subcategories: Identification games, Game - What shall Santa Claus bring you?, BAC training - Europe and Romania, Animal MEMO, GEO Snake Game, and Geography test.

Among the games of identification on the map, in the Romania section there are games that focus on: climate, rivers, lakes, relief units, counties, cities, protected areas. In the Europe section, the identification 
games cover topics such as: climate, rivers, countries, capitals and relief. There are also three identification games targeting landforms: those resulting from abrasion, the magmatic and the volcanic landscape.

Various games can be found in this section, some more interesting, others even boring, as shown by some comments on the website, written by different users: "It's ultra-mega boring."; "Interesting ...oh, eh, BUT ALSO BOORING"; "It is super cool".

From the reviews, it appears that the games that require the identification of some elements on the map (rivers, cities, districts) are the most appreciated by users. We render a few comments concerning these games: "I did best at Geography among all the exams!!!: X"; "Beautiful game and I learned more easily this way"; "Congratulations, teacher!!! I APPRECIATE YOUR WORK!!!"; "Interesting game, and fun :))"; "The game is beautiful, but I never managed to get all the presents. Next time I'll try harder" (about the game "What shall Santa bring you?"); "Hi, I'm a $4^{\text {th }}$ grade primary school student and these games have helped me greatly for tests".

These comments belong mostly to pupils, but there are also comments from teachers on the website, from students and other adult persons interested in certain Geography issues.

Table 4. Games on the website www.profudegeogra.eu

\begin{tabular}{|c|c|c|}
\hline \multirow{17}{*}{$\begin{array}{l}\text { Identification } \\
\text { games }\end{array}$} & \multirow[t]{7}{*}{ Romania } & Climate \\
\hline & & Rivers \\
\hline & & Lakes \\
\hline & & Relief units \\
\hline & & Counties \\
\hline & & Cities \\
\hline & & Protected areas \\
\hline & \multirow[t]{5}{*}{ Europe } & Climate \\
\hline & & Rivers \\
\hline & & Countries \\
\hline & & Capitals \\
\hline & & Relief \\
\hline & \multirow[t]{3}{*}{ Landforms } & Abrasion landforms \\
\hline & & Volcanic relief \\
\hline & & Magmatic relief \\
\hline & \multicolumn{2}{|c|}{ The planets of the Solar System } \\
\hline & \multicolumn{2}{|c|}{ Continents of the world } \\
\hline \multicolumn{3}{|c|}{ Game - What shall Santa bring you? } \\
\hline \multicolumn{3}{|c|}{ BAC training - Europe and Romania } \\
\hline \multicolumn{3}{|c|}{ Animal MEMO } \\
\hline \multicolumn{3}{|c|}{ GEO Snake Game } \\
\hline \multicolumn{3}{|c|}{ Geography test } \\
\hline
\end{tabular}

\section{Analysis of the resources provided for free download}

In the Download books section, there are 52 posts that include Geography books and courses that can be downloaded for free. Among them, there are 4 Geomorphology books/textbooks, 6 Meteorology-Climatology books/ textbooks, 3 Political Geography books, 1 about Topography, 1 Geology book and many more on other various topics of Geography.

We note that not all of these books are readily available. When accessing the following books: "Geology of Romania", "the Romanian Caves", "General Climatology", "Geography of Europe", "Geography of Earth's Natural 
Environments", "America", we receive the message: "Page not found" (Accessed: January 16, 2015). This problem has been noted by users who requested explanations in the Comments section. We suggest the author a revision or total elimination of these posts, in order not to mislead users.

\section{Other resources promoted by the website www.profudegeogra.eu}

This website promotes various educational platforms (e.g. Myacademy.ro which offers mathematics lessons, geografialumii.ro), various scientific articles, online geographical themed games, Geography magazines (e.g. National Geographic, Terra Magazine). They appear on the website as active icons, and when the users check them, they directly access to those pages.

\section{Analysis of users' opinions}

The users' opinions can be best observed in the comments they write on the website, which are mostly positive, but there are also a few more critical comments.

A website user drew the authors' attention to some misspelling: "The website is awesome, except for some grammatical errors that I noticed (e.g.: ISTANBUL is right, not ISTAMBUL; correct spelling is $<<R E \hat{I} N C E P E>>$, not $<<R E A \hat{N} C E P E>>$ ). It would be good to correct all of these mistakes, so that those who come here can learn properly if they learn something."

The answer of the author of the website to this comment was: "Thanks for the feedback! Those who enter this site are not interested in Romanian grammar, but in learning Geography. If they want to learn grammar, I can guide them to the website http://www.profuderomana.ro/. They can find a lot of interesting things there!"

In our opinion, it is important that all the texts in Romanian language and all the names posted on the Internet to be spelled correctly, much more if they are assigned to a teacher. In "School curricula. Geography. From the $5^{\text {th }}$ to the $8^{\text {th }}$ grade", it is specified that a general competence that should be formed and developed in students during the classes of Geography is "the fair use of proper names and terms in foreign languages" (Ministry of Education, Research and Innovation, 2009, p. 6).

In addition to the comments on the website, we used the survey method to quantify the users' opinions about the usefulness and relevance of the resources provided by this website. After analyzing the responses of the 27 students who completed the survey, we came to some conclusions.

On the first question, "Have you ever accessed the website www.profudegeogra.eu?", 96\% of students responded with "Yes". Therefore, only one student has never accessed this website.

Responses to the question "If you were a teacher, would you use the resources provided by the website www.profudegeogra.eu?" showed us once again that the resources offered by this website are considered useful in teaching Geography, 93\% of Geography students answering "Yes" to this question. 
Most students (89\%) said they sought information on this website as students and less as pupils ( $56 \%$ ), and 12 of them said they accessed this website both in the period when they were pupils, but also after becoming students.

Questions 4 and 5 were asked in order to identify the categories of resources provided by the website and which ones are most often used by students and pupils. In Figure 1 and Figure 2 we see that the maps are used by both students and pupils. Following the maps, the most used resources by pupils are tests (44\%) and games (37\%), while students often use the worksheets $(41 \%)$ and books (37\%) provided by the website.

This makes clear the fact that most resources accessed or downloaded by users change according to their age and background (e.g. the books provided on the website are rarely used by pupils). The fact that only a few pupils access the section "Download books" is explained by the fact that these books are scientific books concerning specific issues from different branches of Geography or related fields: "Organisation of geographical space", "Agro-meteorology", "Topography and Cartography", "Physics of the Atmosphere" etc.

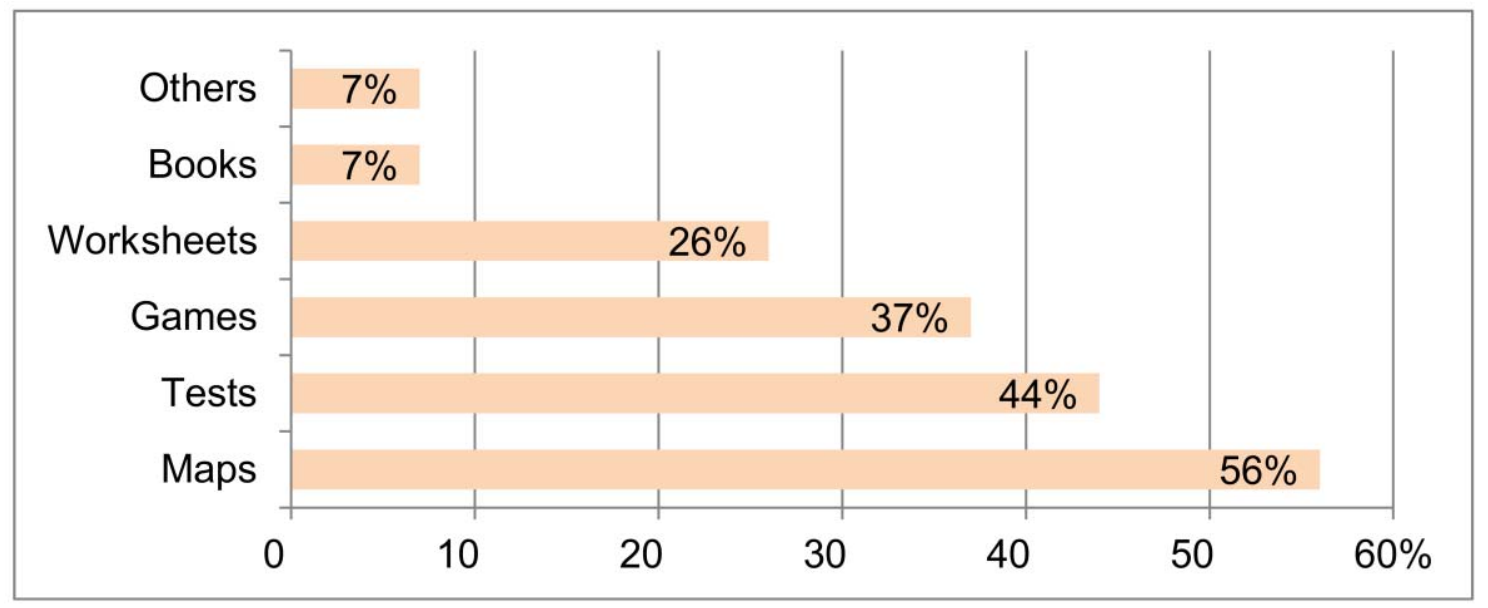

Fig. 1. Resources used by the respondents, as pupils

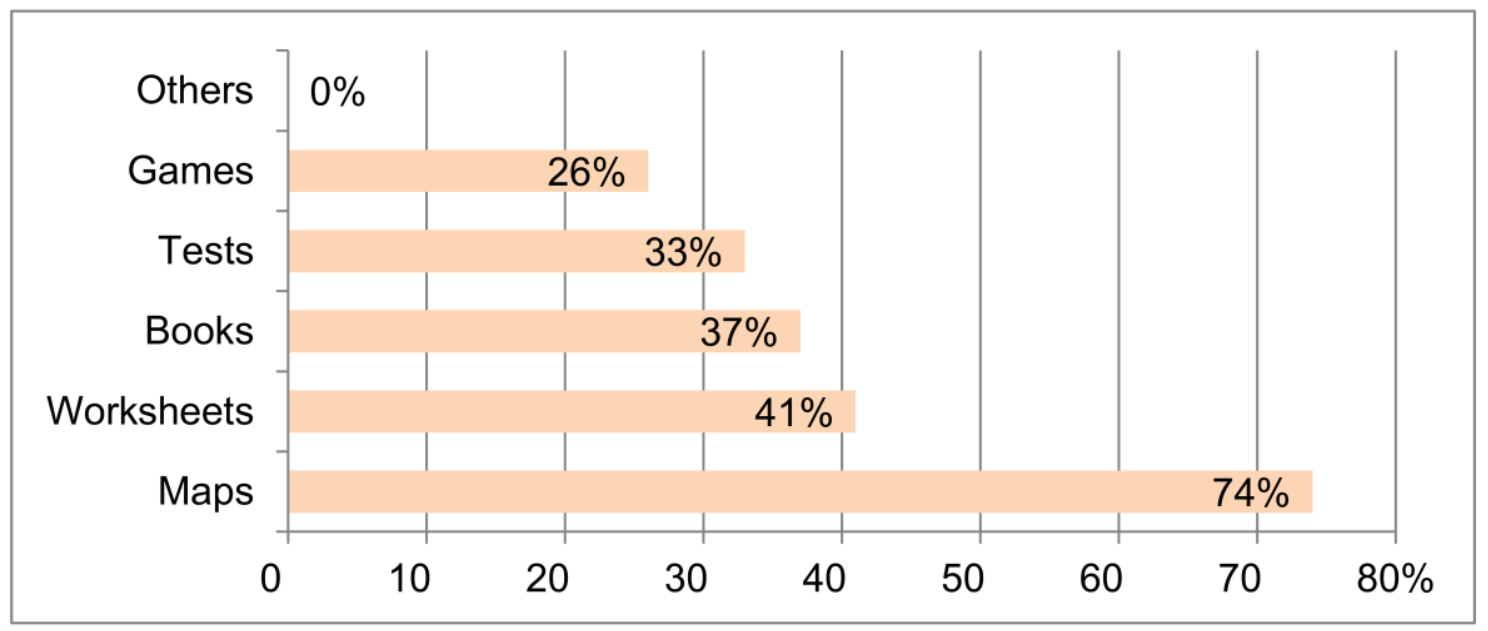

Fig. 2. Resources used by the respondents, as students 


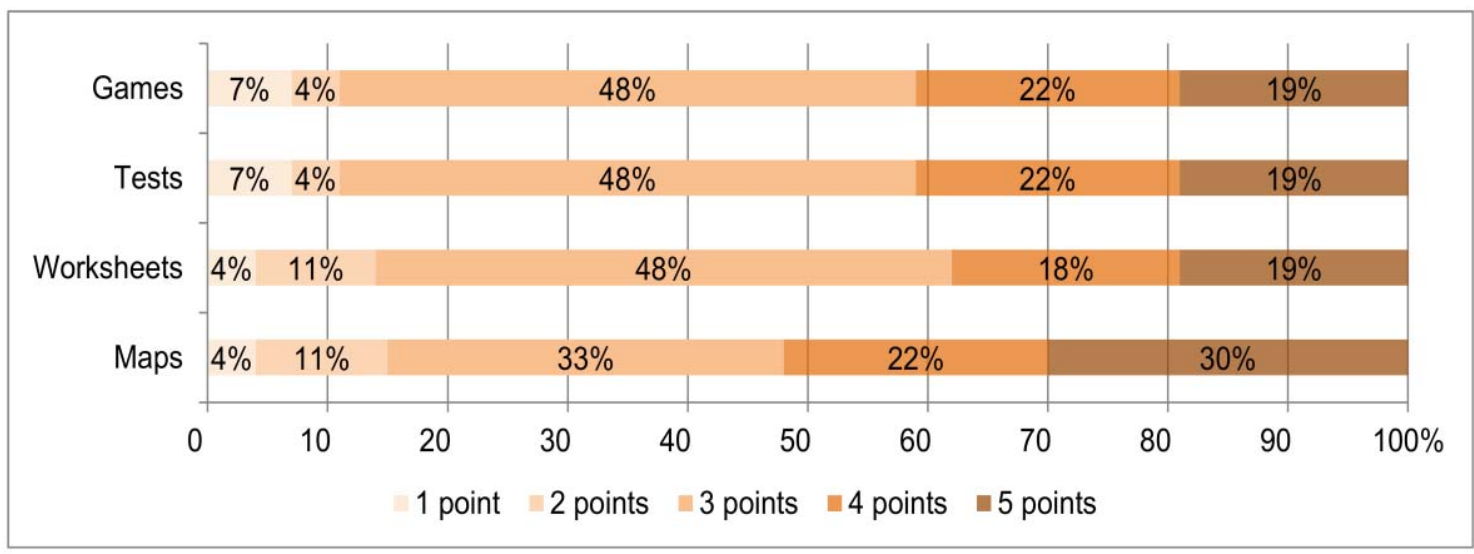

Fig. 3. The degree of appreciation of the various resources provided by the website

In case of the $7^{\text {th }}$ item (Fig. 4) students were asked to score each feature of the website from a list of features, on a scale from 1 to 5 points, given the degree of appreciation they have for that particular feature ( $1=$ poor, $2=$ very little, 3 = average, $4=$ much and $5=$ very much).

We were interested in how much the students appreciate the fact that the website www.profudegeogra.eu combines geographic information with commercials. The majority of the students (44\%) appreciate very little or not at all $(19 \%)$ this aspect, which is understandable, because the ads distract and cover information.

A large percentage of students (33\%) appreciated that the website combines geographic information with those from other subjects, which proves their opening to interdisciplinary subjects. Also, an unexpected percentage of students $(44 \%)$ said that they appreciate the fact that the website contains both scientific and non-scientific information.

The most popular feature of the website, which received the most votes of 5 points (very much), is the fact that the website addresses several age categories: students, Geography teachers and others. This is certainly, in the view of the respondents, a great advantage of the website, which has contributed to the popularity it has today.

The utility of the materials provided by the website is considered medium to high by most of the surveyed students (81\%). However, the reliability on the information published on this website is not high, but rather on average, $48 \%$ of students giving 3 points (average) for this feature. This result is explained by the fact that, in the case of most of the materials provided, the authors are not cited, and neither are the sources from which the information was taken. 


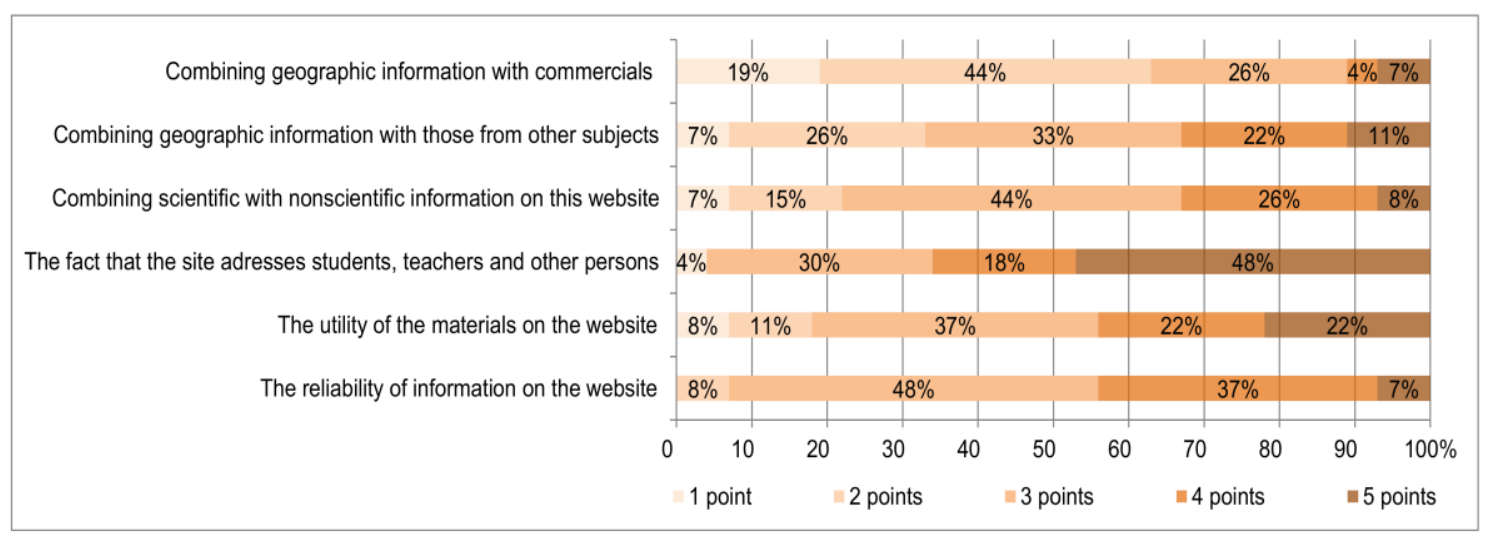

Fig. 4. The degree of appreciation of some features of the website

\section{CONCLUSIONS}

Following the analysis of the website www.profudegeogra.eu and the evaluation of the survey applied, we concluded that this website presents a great utility and is appreciated by pupils, teachers and students.

We appreciate as beneficial that the website addresses teachers, as well as pupils or students, providing various resources according to their diverse needs. A few issues that create e-Learning difficulties are: the grammatical and spelling errors in the texts on this website, the presence of commercials and some unscientific data, and difficulty to verify information.

Following the analysis and the evaluation of the survey results, we found that, among students, the most commonly used resources are the maps $(74 \%)$, being also the most appreciated resource. These are followed by worksheets, books and tests, ordered by the popularity level.

At the end of this study we appreciate that the website www. profudegeogra.eu has a great reputation among Geography students and that it is in the top lists of results found by Google.ro platform when searching for some geographical terms or places in Romania or the world. In the future we hope that the degree of trust in the information provided by the website will grow, as a consequence of posting only clear, concise and accurate materials, taken from original, cited sources.

\section{References}

Buckley, A., \& Frye, C. (2011). Web Map Use and Design: Shifting the Cartography Paradigm. Proceedings of the 25th International Cartographic Conference, Paris, France, 3-8 July 2011, Retrieved January 21, 2015, from http: //icaci.org/files/documents/ICC_proceedings/ICC2011/Oral\%20Presentat ions\% 20PDF/E1-Symbols, \% 20colors\% 20and\% 20map\% 20design/CO-418. pdf 
http://www. profudegeogra.eu/, Retrieved J anuary 16, 2015.

https://www.facebook.com/pages/Profu-de-geogra/235575243125331, Retrieved January 18, 2015.

http://www. geografilia.blogspot.ro/, Retrieved J anuary 18, 2015.

http://www. geografialumii.ro/, Retrieved J anuary 21, 2015.

http://www. didactic.ro/, Retrieved J anuary 22, 2015.

Ministerul Educației, Cercetării și Inovării. (2009). Programe şcolare. Geografie. Clasele a V-a - a VIII-a, București.

Osaci-Costache, G. (2012). La formazione delle competenze professionali nella specializzazione in Cartografia attraverso I'uso delle fonti cartografiche web e dei programmi gratuiti, liberi e Open Source/ Professional skills training on mapping specialization using web mapping sources and freeware, free and Open Source programs. Bollettino dell'Associazione Italiana di Cartografia, XLVIII, no. 144-145-146, pp. 125-135.

Osaci-Costache, G., Cocoş, O., \& Cocoş, A. (2014). Online Cartographic Materials for Geographical Higher Education: Opportunity or Threat? In Vlada, M., Albeanu, G., \& Popovici, D.M. (eds.). Proceedings of the 9th International Conference on Virtual Learning ICVL 2014, Bucharest, 24-25 oct. 2014, Editura Universității din București, pp. 218-224. 